\title{
Journalistic construction of congruence: Chinese media's representation of common but differentiated responsibilities in environmental protection
}

\begin{abstract}
This research clarifies China's mediated international communication of China's responsibility in environmental protection under the principle of common but differentiated responsibilities. The topic is explored within the context of China's media "going global" project, a key initiative of China's soft power projection. Gauged by the notion of cultural and political congruence, this study also compares China's journalistic discourse with those in the US and UK. It found that Chinese mainstream media achieved a certain degree of congruence in media representations of China's responsibility with their Western counterparts. Chinese media constructed the notion of responsibility in a mixed manner: they differentiated the target of blame and existing treatment measures between China and other countries or institutions but gave more exposure to China's future obligations and duties. American and British media applied nearly identical coverage patterns in reporting China's and others' existing and future treatment but showed opposite patterns in covering the target of blame in environment and climate issues. This paper contributes to the study of China's journalism practice in international communication. It also offers suggestions to the resolution of the stalemate in global environmental negotiations and China's media "going global" initiative.
\end{abstract}

Keywords: international responsibility; environment and climate; journalistic construction; cultural and political congruence; Chinese media

\section{Introduction}

Whether a country's political or socio-cultural messages can be acknowledged and even practiced with willingness by other countries may impact the 'international political process and outcome' (Wang, 2006: 91). This is what Joseph Nye (1990, 2004, 2008, 2010) refers to in his notion of 'soft power', which justifies the American cultural and political values. The notion was soon embraced by other countries, including China. It is notable that mainstream Chinese intellectuals and politicians have their own interpretations of China's soft power. They mainly regard China's cultural attractiveness, as well as its political power, as China's core soft power resources and view soft power as both domestic and international development strategies (Glaser and Murphy, 2009). Nevertheless, both explanations agree on the idea of using messages and values, instead of weapons or sanctions, embedded in culture or policies to influence others and obtain what you want. Guided by this philosophy, the Chinese government proactively mediated messages of, for example, a 'correct version' of China through the Confucius institutes (Hartig, 2015), an ascending prosperous and well-organised nation through Beijing Olympic Games (Brownell, 2013), China's understanding of global order through China Central Television (Zhang, 2013), and the globalisation of China's culture through media products of commercial and state-owned media institutions (Lee, 2014). 
This study put foci on the mediated messages of the principle of common but differentiated responsibilities (hereafter, CBDR) constructed and delivered by China's mainstream international media which are dedicated to China's image management and soft power generation initiatives. The principle of CBDR is the core of international climate politics (Post et al., 2018). However, it is diversely interpreted because of its loose definition (Matsui, 2002; Stone, 2004). Taking advantage of the national strategy of soft power projection, the Chinese government may construct its interpretations of the principle of CBDR and strive to make this discourse accepted by others through mediated channels. This presumption is based on the following considerations. By emphasising the dynamism of attraction, Joseph Nye argued that three major resources, 'its culture (in places where it is attractive to others), its political values (when it lives up to them at home and abroad), and its foreign policies (when they are seen as legitimate and having moral authority)' (2004: 11), can generate soft power for a country. It is safe to presume that the messages of China-related responsibilities in environmental protection, which form one of the core elements in China's foreign policies, are included in China's soft power initiatives. One piece of evidence is China's pledges to the 2015 Paris Agreement, which was dissected by Harris (2017) as one of China's endeavours to make China's foreign policies recognised by the international community and generate soft power. The outbound communication through transnational news media institutions may be employed as the key channels, especially after the launch of the media "going global" project, which was lavishly invested by the Chinese government as an essential element of China's impression-improvement strategies (Hu et al., 2013). Moreover, the Chinese leadership stressed the necessity of conveying China's perspectives in outbound communication (Li, 2010), which is commonly defined as securing the power of discourse by the Chinese politicians (Cunningham, 2012). Therefore, China's mainstream transnational media institutions probably constructed the messages in their own frames, aspiring to be accepted by overseas audiences and generate soft power.

The notion of mediated public diplomacy and cultural and political congruence (Entman, 2008; Sheafer and Shenhav, 2009) illuminates the direction of the construction of mediated messages in effective international communication. It stresses the importance of overlap of the dominant political cultures between the projecting and the receiving nations in the acceptance of the mediated messages. The journalism scholarship is rich in examining the outcome of China's mediated public diplomacy. For instance, scholars found their limited influence on global information flow and foreign audiences' perceptions of China's national branding (Zhang, 2008) and the image of Chinese leadership (Cheng et al., 2016), or their substantial influence on international news coverage on the 2014 Hong Kong Protest (Zhang et al., 2018) and on major global affairs marginalised by Western media (Zeng, 2010). The academia also extensively explored the underlying problems in China's international communication, such as the production values, professionalism, credibility, and market structures (Lee, 2014; Xin, 2009), the politicised messages and values employed by the Chinese government (Hartig, 2015), the wider Chinese socio-political and ideological environment (Ding, 2011), and its difference with that in other countries, especially Western countries (Sun, 2014). However, there is a lack of research on how the mechanism of cultural and political congruence impacts the journalistic construction of international communication messages. This study will be the first one that delves into this topic. Through clarifying 
China's mediated messages of China's responsibility under the principle of CBDR, this study is theoretically significant in revealing the application of cultural and political congruence in China's international communication. It is also of vital empirical importance to China's, as well as other countries', future strategic international communication, especially in breaking the stalemate in global environmental negotiations.

Following the introduction, this paper reviews existing studies on China's role in the global environmental protection under the principle of CBDR and the theoretical framework of mediated public diplomacy and cultural and political congruence. It then details the sampling procedures of Chinese and Western media and the research method of qualitative content analysis. The research findings are displayed according to the themes of emission issues, international assistance, international cooperation, and the compliance with the principle. In the discussion section, this paper explains the research findings based on the theory of cultural political congruence, clarifies the theoretical and empirical contributions, and proposes future research agendas.

\section{China's involvement in global environmental protection and the principle of CBDR}

The battle of discourses seemed intensive between China and other national and institutional members on China's role in global environmental protection. China was criticised for becoming 'the largest national source of pollution causing climate change' (Harris, 2011: 2). Nevertheless, the Chinese government hesitated to accept its responsibilities in, for example, fulfilling mandatory emissions-reduction targets since the 1980s when global negotiations on climate change initiated (Harris, 2011). The major ethical reasons that the Chinese government insisted were: one, the developed countries should shoulder the responsibility ahead of others since their development was at the cost of the environment; two, China as a developing country should prioritise domestic development (Harris, 2011). With the disasters caused by environmental damages escalating, the rest of the world exhorted the Chinese government to undertake responsibilities in environmental protection. In 2005, former US deputy secretary of state Robert Zoellick (2005) claimed that 'We need to urge China to become a responsible stakeholder in that system' (emphasis in original). Echoing this statement, in the domain of environmental protection, various institions and politicians specified China's, along with other countries', responsibilities in climate change, energy policy, and other areas of environmental protection (see Commission of the European Communities, 2006; Merkel, 2007; The White House, 2010).

Hoo (2013: 171) observed that 'Washington never explicitly specified what it thought these responsibilities should be' and 'At the official level, Chinese leaders... did not go beyond general assertions or claims'. The vagueness of the political languages perhaps can be attributed to the trickiness of defining responsibility. Furthermore, as to the question '[Is] China responsible for climate change', Harris answered that 'Not surprisingly, the answer must always be prefaced by 'it depends" (2011: 18). In other 
words, there is still much space to interpret China's involvement in global environmental protection issues by China itself and by others.

The situation shows no difference when it comes to the core principle of international climate politics, the principle of CBDR (Post et al., 2018). It was firstly explicitly addressed in the Rio Declaration at the 1992 United Nations Conference on Environment and Development (Rajamani, 2000; Stone, 2004). It was defined in Principle 7 which reads:

States shall cooperate in a spirit of global partnership to conserve, protect and restore the health and integrity of the Earth's ecosystem. In view of the different contributions to global environmental degradation, States have common but differentiated responsibilities. The developed countries acknowledge the responsibility that they bear in the international pursuit of sustainable development in view of the pressures their societies place on the global environment and of the technologies and financial resources they command. (United Nations, 1992)

The principle is of vital importance in global environmental protection that it has guided the law-making of global environmental protection conventions including the United Nations Framework Convention on Climate Change (UNFCCC) and the Kyoto Protocol (Matsui, 2002). ${ }^{1}$ Nevertheless, the loose definition of the principle induces different interpretations, such as different emphasis of the two elements of the principle, namely the common responsibilities and the differentiated responsibilities (Matsui, 2002). The scholarly debates well reflected the discursive conflicts among countries concerning the international environmental protection issues. Adding to the discursive chaos is the fact that as a 'fundamental principle of international environmental law', this principle can not initiate 'concrete legal operations or consequences' but only be activated when using along with conventions and judged by the context (Matsui, 2002: 166).

The diverse interpretation of a country' responsibilities in global environment and climate issues not only appears in the domain of international law but also in environmental communication. For example, Post and collaborators (2018) found that media in developed and developing countries significantly less attributed the casual responsibility, i.e. blame for environmental problems, to the in-group members, evidencing the 'in-group-protecting patterns' (p. 13). Similar conclusion was also obtained by Liang et al.'s (2014) research on Chinese TV which shifted the blame to developed countries in its news coverage of the 2009 UN climate change conference in Copenhagen.

However, the journalistic representations of 'in-group favoritism' and 'out-group derogation' (Post et al., 2018) are not helpful for achieving agreement in global environmental negotiations. It further induces three questions. Firstly, does that mean there is no common ground between different countries in their journalistic representations of environmental protection issues and there will be never-ending arguments on the notion of responsibility? Secondly, as to the case of China, who is proactively engaging in the media "going global" project and soft power projection, is it 
applying the same or a different way of mediated communication in representing China's involvement in the principle of CBDR? Thirdly, if China does apply a different manner of journalistic representation, then how? Discussing China's journalism practice in international communication under the backdrop of China's soft power projection, this study assumes that it will comply with the mechanism of cultural and political congruence.

\section{Mediated public diplomacy and cultural and political congruence}

The process that the practicing country promotes its agendas and messages, especially of its foreign policies, through mediated channels and tries to exert influence on the target country's mediated channels is defined by Entman (2008) as mediated public diplomacy. The concept links the scholarly interest in the mutual influence of media agendas and/or frames, which is widely discussed in the intermedia agenda setting scholarship (e.g. Vonbun et al., 2016; Jang et al., 2017), with the political intentions of gaining acceptance and trust in the international area. It is viewed as one of the most important mechanisms of garnering attraction in soft power practices (Entman, 2008) since it is effective 'to create consensus around shared meaning' (Roselle et al., 2014: 72) and 'to increase mutual understanding and respect of differences through positive media messages' (Servaes, 2016: 440). The reason is that it goes beyond the ideas such as glocalization (Robertson, 1995) and the technical measures such as adapting to local media languages and formats (Chang, 2003; Wu, 2008) by considering the acceptance of messages and values in the media products in other countries to achieve the above communicative purposes.

Scholars including Entman (2008) and Sheafer and Shenhav (2009) thus concluded the essence of mediated public diplomacy with the notion of cultural and political congruence, which refers to the degree of overlap of the dominant political cultures between the projecting and the receiving nations. Existing studies evidenced the importance of cultural and political congruence in international communication. For example, Sheafer and Gabay (2009) confirmed the in regards to the issues of Israel's disengagement from Gaza and the general elections in the Palestinian Authority, media agendas and framings from Israel were better received in the US than in British media and the opposite happens to the Palestinian Authority, and the higher cultural political proximity between an antagonist and a foreign country plays a positive role in the acceptance of media language in another country. Once again, Sheafer et al. (2014) identified that the relative political proximity between Israel and a foreign country is an effective indicator of the acceptance of Israel's news framing in the Gaza War.

The key of China's media "going global" project, as required by the Chinese government, includes 'enabling foreign people to hear the voice of China' (Hayden, 2012: 181) and prioritising the dissemination of China's 'social development, and internal and external policies' (Zhao, 2011) through the channel of mediated public diplomacy. Existing studies have documented the proactive measures that the Chinese government adopted in promoting mediated public diplomacy (e.g. Cheng et al., 2016; Zhang et al., 2018). To overcome the pre-existing cultural and political distance between the Chinese and the Western society, this study assumes that China's outbound media 
will strive to construct journalistic messages concerning China's foreign policies in congruence with those in other countries. Based on Entman's (2008: 94) illustration of the interrelationship between the degree of cultural and political congruence of two societies and US's projection of soft power messages in receiving countries' mainstream media institutions, this study proposes another one which is specific to China's journalism practice in international communication (see Figure 1).

[insert Figure 1.]

Previous studies have contributed to the examination of Chinese media's endeavours in the construction of mediated messages in international communication. For example, Boc (2015) argued that China's construction and promotion of the notion of African Dream was based on their shared colonised historical background and similar development objectives. Although the primary purpose, as contended in the study, was to make attractive and acceptable China's new political slogan of 'the Chinese Dream', the above construction and dissemination strategies may probably produce promising outcomes in Africa (Boc, 2015). On the contrary, Hartig (2015) concluded that the messages communicated by the Confucius Institutes largely bypassed politically sensitive issues and mapped a 'correct version' of China to others, inducing credibility issues among foreign audiences. Focusing on the construction of China's responsibility in global environmental protection under the principle of CBDR, the first research question this study aims to answer is:

RQ1: What were China's mediated messages of China's involvement in the principle of common but differentiated responsibilities during China's media "going global" project?

To better illustrate how much congruence of journalistic messages that Chinese outbound media achieved with those in the media outlets in other countries, this study also tries to unearth the journalistic representations in American and British media by asking:

RQ2: How did American and British mainstream media portray China's involvement in global environmental protection issues when they interpreted the principle of common but differentiated responsibilities during China's media "going global" project?

\section{Research Methods}

\section{Selection of Chinese media and sampling}

This study used English-language news articles from the newswire of Xinhua News Agency and the newspapers (including their online data) of China Daily, People's Daily, and Global Times. These media institutions were selected because they were among the most supported media institutions during China's media "going global" project and serve as a significant part of China's international discourse construction initiatives (d'Hooghe, 2011; $\mathrm{Hu}$ and $\mathrm{Ji}, 2012$ ). Table 1 provides a brief introduction of the selected Chinese media. 
This study retrieved news articles from $1^{\text {st }}$ January 2009, a year witnessing China's launch of the media "going global" expansion scheme, to $31^{\text {st }}$ December 2016, the last year before Donald Trump's 2017 presidency which reshaped the world's political landscape. For example, environmentally, his announcement that he would withdraw the United States from the Paris Agreement was regarded as handling the global leadership on climate change to China (Sanger and Perlez, 2017). It located news articles with the exact phrase "common but differentiated" from the Dow Jones Factiva database. The source of the database was restricted to the "Xinhua - All sources" "China Daily - All sources" "People's Daily Online (China)" "Global Times (China, National Edition)" and "Global Times (China, Web Edition)" and the region was restricted to "China". A total of 345 news articles were selected after excluding the news articles covering non-environmental issues and with non-national level perspectives and duplicated ones. The basic information about the Chinese media and the amount of selected news articles respectively were recorded in Table 1.

Table 1. Information about the Chinese media institutions

\begin{tabular}{|c|c|c|c|c|}
\hline $\begin{array}{l}\text { Media } \\
\text { names }\end{array}$ & Type & Slogan & $\begin{array}{l}\text { Start of } \\
\text { English- } \\
\text { language } \\
\text { service }\end{array}$ & $\begin{array}{l}\text { Amount of } \\
\text { news } \\
\text { articles }\end{array}$ \\
\hline $\begin{array}{l}\text { Xinhua } \\
\text { News } \\
\text { Agency }\end{array}$ & $\begin{array}{l}\text { Press } \\
\text { agency }\end{array}$ & $\begin{array}{l}\text { 'Xinhua News Agency should } \\
\text { manage the world, so that } \\
\text { the whole world can hear the } \\
\text { voice of China.' }\end{array}$ & 1944 & 186 \\
\hline $\begin{array}{l}\text { China } \\
\text { Daily }\end{array}$ & $\begin{array}{l}\text { Daily } \\
\text { newspaper }\end{array}$ & $\begin{array}{l}\text { 'A voice of China on the } \\
\text { global stage' }\end{array}$ & 1 June 1981 & 150 \\
\hline $\begin{array}{l}\text { Global } \\
\text { Times }\end{array}$ & $\begin{array}{l}\text { Daily } \\
\text { newspaper }\end{array}$ & $\begin{array}{l}\text { 'Discover China. Discover the } \\
\text { world.' }\end{array}$ & 20 April 2009 & 7 \\
\hline $\begin{array}{l}\text { People's } \\
\text { Daily }\end{array}$ & $\begin{array}{l}\text { Daily } \\
\text { newspaper }\end{array}$ & N.A. & $\begin{array}{l}14 \text { January } \\
1998\end{array}$ & 2 \\
\hline
\end{tabular}

Note: Information were retrieved from the official websites of the media institutions.

Selection of American and British newspapers and sampling

This research put specific foci on pertaining media representations in American and British newspapers. The selection of American and British newspapers was based on two considerations. Firstly, they paid attention to the principle of CBDR and involved China in their interpretation of the principle. This study narrowed down the search scope with 
the aid of the sources of "Major US Newspapers" and "UK Newspapers" in the database of Nexis UK by restricting the country to "China" and requesting documents with "common but differentiated" in the body. Secondly, they are daily quality newspapers with large circulation size. They may set Western media, political, and public agendas and frames and may be the target of China's mediated public diplomacy. This study complemented the above database with Dow Jones Factiva. Table 2 and 3 list the information about the American and British media.

Table 2. Information about the American newspapers

\begin{tabular}{lll}
\hline Newspaper names & Daily circulation (print and digital) in 2017 & $\begin{array}{c}\text { Amount of } \\
\text { news articles }\end{array}$ \\
\hline The New York Times & $360,000^{\mathrm{a}}$ & 7 \\
The Wall Street Journal & $2,520,000^{\mathrm{b}}$ & 6 \\
The Washington Post & $425,420^{\mathrm{c}}$ & 3 \\
\hline
\end{tabular}

Note: a. Retrieved from "The New York Time Company-2017 annual report" (http://www.annualreports.com/HostedData/AnnualReports/PDF/NYSE_NYT_2017.pdf) ; b. Retrieved from "News Corp- Report 2017" (https://newscorpcom.files.wordpress.com/2017/10/3-attachment-2017-annualreport.pdf); c. Retrieved from its official website (https://www.washingtonpost.com/wpstat/ad/public/static/media_kit/2018AdBook.pdf) and the news report by NBC News (https://www.nbcnews.com/news/us-news/washington-post-still-plays-catch-gainingtimes-n833236).

Table 3. Information about the British newspapers

\begin{tabular}{lcc}
\hline Newspaper names & Daily circulation (print and digital) in 2017 & $\begin{array}{l}\text { Amount of } \\
\text { news articles }\end{array}$ \\
\hline The Guardian & $230,000^{\mathrm{d}}$ & 15 \\
The Independent & $1,354,000^{\mathrm{e}}$ & 7 \\
Financial Times & $910,000^{\mathrm{f}}$ & 5 \\
The Telegraph & $476,466^{\mathrm{g}}$ & 2 \\
The Times & $619,905^{\mathrm{h}}$ & 1 \\
\hline
\end{tabular}

Note: d. Retrieved from "Working report, Guardian Media Group 2017-2018" (https://www.theguardian.com/info/ng-interactive/2018/jul/24/working-report); e. Retrieved from "https://www.newsworks.org.uk/the-independent"; f. Retrieved from 
"Financial Times Annual Results 2017" (https://aboutus.ft.com/engb/announcements/financial-times-annual-results-2017/); g. Retrieved from "Audience" (http://spark.telegraph.co.uk/toolkit/advertising/audience/); h. Calculated based on data from "News Corp- Report 2017" (https://newscorpcom.files.wordpress.com/2017/10/3attachment-2017-annual-report.pdf)

\section{Qualitative content analysis and data}

The research method of qualitative content analysis was applied in this study to interpret and analyse the content of the news articles 'through the systematic classification process of coding and identifying themes or patterns' (Hsieh and Shannon, 2005: 1278). This study applied the approach of directed content analysis by applying the key categories of the notion of national responsibility in environmental protection examined in previous studies (Liang et al., 2014; Post et al., 2018; Zhao, 2017) and then defining the operational definitions for each category (Hsieh and Shannon, 2005). Specifically, this study investigated how the news articles defined common blame for, common treatment of, differentiated blame for, and differentiated treatment of environmental problems. Accordingly, it designed the categories as "blame China", "blame others", "China's existing treatment", "China's future treatment", "others' existing treatment", and "others' future treatment", whose operational definitions are displayed in Table 4. After sifting through the news articles thoroughly, this study chose to focus on the following themes: emission issues (including causes of the polluted air, setting of emission reduction targets, and negotiation of emission reduction), international assistance in finance and technology, international cooperation in finance and technology, and the principle in a general sense (including stances towards and actions under the principle in a general sense). These themes are consistent with existing studies on the notion of responsibility in environmental protection (Post et al., 2018; Zhao, 2017). To complement the descriptive interpretation of the patterns in the Chinese and Western news articles, this study also illustrated the 'rank order comparisons of frequency of codes' (Hsieh and Shannon, 2005: 1283).

Table 4. Operational definitions of categories and quotations

\begin{tabular}{lll}
\hline Category & Operational definition & Quotation \\
\hline Blame China & $\begin{array}{l}\text { The Chinese government or } \\
\text { China overall is the cause of } \\
\text { environmental and climate } \\
\text { problems. }\end{array}$ & $\begin{array}{l}\text { 'China, as one of the world's } \\
\text { biggest GHG emitters' (China } \\
\text { Daily, 24 August 2009) }\end{array}$ \\
$\begin{array}{ll}\text { Other country or institution is } \\
\text { the cause of environmental } \\
\text { and climate problems. }\end{array}$ & $\begin{array}{l}\text { 'Most industrialized countries, } \\
\text { which contributed three } \\
\text { quarters of the world's total } \\
\text { GHG emissions in the second } \\
\text { half of last century, fell short } \\
\text { of commitments that they }\end{array}$ \\
\hline
\end{tabular}




\begin{tabular}{ll}
\hline China's existing & The Chinese government or \\
treatment & China overall is providing or \\
& has provided solutions to \\
& environmental and climate \\
& problems.
\end{tabular}

signed up in the Kyoto

Protocol' (Xinhua News

Agency, 25 August 2009)

'African countries (...) have been receiving a lot of support from China, which showed a major power's responsibility over global environmental protection' (China Daily, 19 May 2013)

Others' existing treatment

Other country or institution is

‘...) some \$28 billion had providing or has provided already been committed by solutions to environmental and climate problems. developed countries (...) that will assist mostly developing countries in mitigating the effects of climate change between 2010 and 2012' (China Daily, 5 October 2010)

China's future treatment

Others' future treatment

The Chinese government or

'China fully (...) advocates China overall will provide or is effective multinational asked to provide solutions to collaboration and common environmental and climate problems. efforts' (Xinhua News Agency, 25 August 2009)

Other country or institution 'The developed countries (...) will provide or is asked to provide solutions to environmental and climate have the obligation to promote international cooperation, including problems. honoring their commitments of providing funds and transferring technologies to developing countries such as China' (Xinhua News Agency, 6 February 2009)

\section{Findings}

[insert Figure 2.]

[insert Figure 3.] 


\section{Emission issues:}

Regarding the target of blame in emission issues, the Chinese mainstream media constructed responsibilities as being differentiated between China and other countries or institutions. They blamed other countries or institutions in a slightly more frequent way $(21.45 \%)$ than China (13.62\%) as the cause of the emission issues. What is unexpected is that instead of isolating China itself from the targets of blame, the Chinese media had a considerable amount of news articles $(13.62 \%)$ mentioning that the country is also a part of the air problems. The differentiation of responsibilities in regards to the treatment of emissions issues also happens in the media's coverage of existing measures that China and other countries or institutions have adopted. As shown in Figure 2, the journalistic foci on the previous and ongoing treatment conducted by the Chinese government $(21.45 \%)$ obviously outweighed those by other countries or institutions $(2.32 \%)$. However, the Chinese media also had more coverage of China's future treatment of emission issues and others' urges of China for future measures $(38.84 \%)$, and the frequency of the application of this category even bypassed that of the coverage of future measures acclaimed by other countries or institutions themselves or requested by others (27.54\%). In a word, concerning China's stance towards the CBDR principle in emission issues, the common and differentiated characteristics of the notion of responsibility was blurred in Chinese media's journalistic construction. It tended to blame others more in the cause of air issues and highlighted more of China's existing efforts, but also contributed more news articles to mention China's future missions and burdens.

The trend was also mixed in the news coverage by American and British media as shown in Figure 3. On the one hand, they blamed China more frequently $(58.70 \%)$ as the reason for air issues than others $(34.78 \%)$ and did not follow Chinese media's manner of coverage. On the other hand, same with the coverage by the Chinese media, they also gave more exposure to China's existing $(43.48 \%)$ and future $(65.22 \%)$ treatment measures for emission issues than those by others $(26.09 \%$ and $54.35 \%$ respectively).

\section{International assistance:}

When reporting China's stance in international assistance for environment and climate issues under the principle of CBDR, Chinese media put sole foci on others $(3.77 \%)$ when applying the blame category. It indicates that the target of blame, one aspect of the notion of responsibility, was differentiated by Chinese media's construction. Different with their coverage of emission issues, Chinese media treated the existing treatment measures by China and others equally $(4.35 \%)$ in news reports, implying the common characteristics of responsibility between China and other international members. Nevertheless, the aspect of treatment in the notion of responsibility was constructed as being differentiated regarding the future obligations. According to Figure 2, there were more coverage of others' stances, missions, measures, and burdens $(29.86 \%)$ than those of China $(4.06 \%)$. Once again, there was no obvious trend in Chinese media's construction of blame or treatment in interpreting the idea of responsibility in the CBDR principle.

Interestingly, Figure 3 shows that American and British media also paid equal attention to the previous and ongoing treatment policies and actions conducted by China 
and other countries or institutions $(2.17 \%)$, although the frequency indicates that media reports from both countries, same as those by Chinese media, did not show many interests in this topic. The differentiated feature of future treatment also appeared in Western media's coverage, which put exclusive foci on others' future obligations and duties (13.04\%) in providing international assistance in global environment and climate issues. Different from the differentiated coverage of the target of blame in international assistance by Chinese media, American and British media contributed no news stories to this category.

\section{International cooperation:}

Chinese media's interpretation of China's stance towards international cooperation in environment and climate issues under the principle of CBDR showed a similar trend with their coverage of emission issues. Although the target of blame was again constructed as being differentiated by the Chinese media, the feature was not obvious that only $0.29 \%$ news articles mentioned others' fault in this theme and no articles included China's misconduct. Then China's existing solutions (18.84\%) to environment and climate problems were more frequently covered by Chinese media, although not in a distinct advantage compared with the coverage of others' existing treatment (14.78\%), indicating a slightly differentiated focus by the Chinese media. Same with the reporting of emission issues, Chinese media gave more exposure to China's future obligations and duties $(50.14 \%)$ in international cooperation than those of other countries or institutions $(35.65 \%)$. The journalistic construction indicates that China proactively involved in international cooperation for the facilitation of resolution of global environment and climate issues and treated this as a common obligation. In a word, Chinese media once again blended the construction of common and differentiated features of responsibility in covering international cooperation.

Same with the coverage by the Chinese media, American and British media applied the category of existing treatment more frequently when mentioning China $(26.09 \%)$ than others $(23.91 \%)$. As to future responsibilities in engaging in international cooperation, American and British media devoted equal attention to China and others $(8.70 \%)$. There is no appearance of the application of the category of target of blame in the media reports from both countries.

\section{Compliance with the principle in general:}

There are considerable Chinese, as well as American and British, news stories constructed the notion of responsibility through the theme of compliance with the principle of CBDR. Figure 2 illustrates that same with the coverage of the above three themes, Chinese media also blamed others more frequently $(9.57 \%)$ than China $(2.32 \%)$ for not complying with the principle of CBDR generally. Different with the coverage of the themes of international assistance and international cooperation and same with those of the theme of emission issues, Chinese media also surprisingly included China as the target of blame, although not frequently. Chinese media's construction of existing and future measures in the topic of principle abidance also showed similar trend with the coverage of emission issues and international cooperation. They tended to put more 
efforts in reporting China's existing (31.88\%) and future (76.52\%) treatment than others (7.54\% and 55.07\% respectively), depicting a China who took on more measures under the principle of CBDR and has common, and even more, future obligations. Once again, the construction of the notion of responsibility also showed no obvious trend of being common or differentiated.

Figure 3 displays that American and British media still did not share the same coverage pattern with those by Chinese media in the category of target of blame. Same with the reporting of emission issues, American and British media mentioned China $(8.70 \%)$ as the violator of the principle of CBDR more frequently than others $(2.17 \%)$. Nevertheless, similar with the reporting manner of Chinese media, media of both countries gave more discussion to China's existing $(10.87 \%)$ and future $(52.17 \%)$ stances and actions within the framework of CBDR than those by others $(2.17 \%$ and $34.78 \%$ respectively).

\section{Concluding discussion}

This study uses Table 5 to facilitate the discussion of the conclusion. Table 5 clearly shows that there is high proximity between Chinese and Western media in representing China's existing measures and future treatment efforts in coping with environment and climate issues, but sheer difference in identifying the target of blame.

Table 5. Summary of research findings

\begin{tabular}{|c|c|c|c|c|c|c|c|}
\hline \multirow[t]{2}{*}{$\begin{array}{l}\text { Themes and } \\
\text { categories }\end{array}$} & & \multicolumn{2}{|c|}{$\begin{array}{l}\text { Target of } \\
\text { blame }\end{array}$} & \multicolumn{2}{|c|}{$\begin{array}{l}\text { Existing } \\
\text { treatment }\end{array}$} & \multicolumn{2}{|c|}{$\begin{array}{l}\text { Future } \\
\text { treatment }\end{array}$} \\
\hline & $\begin{array}{l}\text { Media } \\
\text { origin }\end{array}$ & China & Others & China & Others & China & Others \\
\hline \multirow[t]{2}{*}{ Emission issues } & China & & v & V & & $\mathrm{V}$ & \\
\hline & US\&UK & $v$ & & $\checkmark$ & & v & \\
\hline \multirow{2}{*}{$\begin{array}{l}\text { International } \\
\text { assistance }\end{array}$} & China & & $v$ & - & - & & v \\
\hline & US\&UK & & & - & - & & v \\
\hline International & China & & $\mathrm{v}$ & v & & v & \\
\hline
\end{tabular}


cooperation

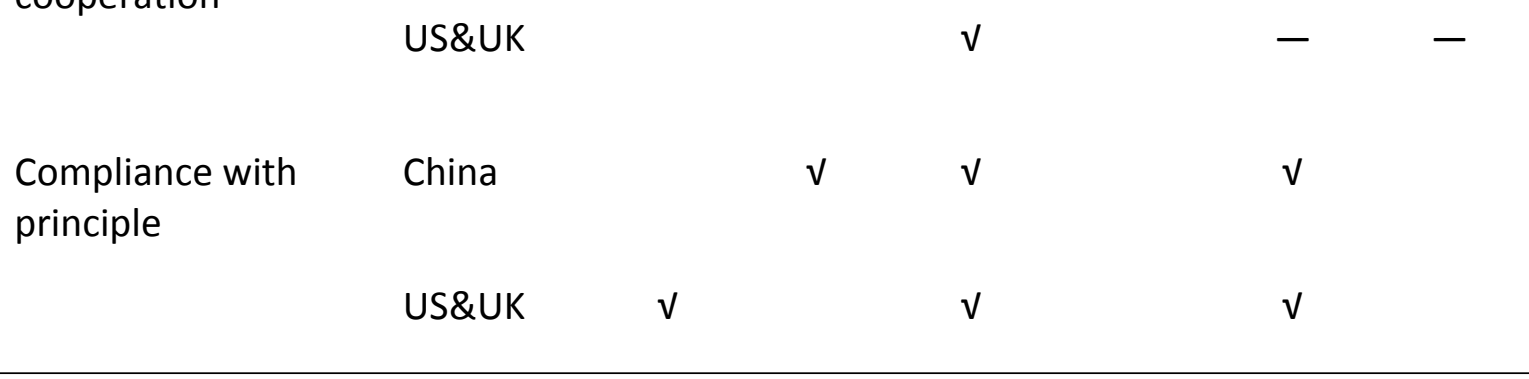

Note: "V" means the frequency of the application of this category in the media outweighs those of the other category in the same theme; "-" means the frequency of the application of this category in the media is equal to those of the other category in the same theme.

The first research question asks China's stance of responsibility in environment and climate issues under the principle of CBDR as constructed by Chinese mainstream media during China's media "going global" initiative. This research finds that Chinese media constructed China's involvement in the related responsibility in a mixed manner. They consistently constructed that the target of blame was differentiated that the news stories mentioned others as the target of blame more frequently than China across all the four themes. This trend also appeared in the coverage of the existing treatment, which is another interpretation of the notion of responsibility. China was more frequently mentioned when reporting existing measures in dealing with emission issues, international cooperation, and compliance with the principle, indicating that the existing treatment was differentiated and China devoted more efforts to the resolution of environment and climate problems. The existing measures adopted by others was only given equal attention when covering the theme of international assistance. Nevertheless, instead of hiding away from China's future obligations, Chinese media gave more exposure to China's future roles in emission issues, international cooperation, and compliance with the principle in general than others, indicating that the future treatment is a common mission for not only others but also China. The future treatment was only constructed as being differentiated when covering the theme of international assistance that others' obligations were given more discussion.

The second research question inquiries Western countries' journalistic construction of the notion of responsibility concerning China's involvement in global environment and climate issues under the principle of CBDR. Unsurprisingly, American and British media had a different focus on the target of blame that they mentioned China more frequently as the cause of air problems and violator of the principle of CBDR. Both Chinese and Western media tended to construct the target of blame as being differentiated between China and others but pointing to opposite directions in these two themes. American and British media did not blame any member when covering the topics of international assistance and international cooperation. An interesting finding appears in the category of existing treatment that the pattern of coverage by American and British media was identical with those by Chinese media. They either highlighted China's existing efforts in themes of emission issues, international cooperation, and compliance 
with the principle or equalised the endeavours by China and others in international assistance, which, in an overall sense, indicates the differentiated existing measures undertaken by China and others. As to future treatment, the coverage patterns also showed high similarity that China's future involvement was mentioned more frequently in covering emission issues and obedience with the principle, others' involvement was given more exposure in international assistance, and equal attention was devoted to international cooperation issues.

The research findings add to the knowledge of cultural and political congruence with the case of China. Driven by the political purpose of receiving resonance among overseas audiences, the Chinese mainstream media were found that partially reached congruence in coverage patterns with their Western counterparts. Empirically, this study provides evidence to the deadlock of the ongoing international environmental negotiations. Media both in China and the two Western countries were found by this paper that shared almost identical coverage patterns in reporting what China has done, has been doing, and is about to do in terms of treatment, that is, the resolutions in environmental and climate problems. However, the causes of the environment and climate problems were represented as being differentiated by Chinese and Western media and showed no sign of congruence in media reports. To facilitate the global environmental negotiations and fasten the environmental protection procedures, future international communication by different countries may want to put more efforts to cover the common resolutions to the environmental problems than blaming and scapegoating. Accordingly, China's media "going global" initiative, which is a core of China's soft power projection, is more likely to achieve congruence with other countries, and probably better acceptance among their audiences, if it disseminates more of China's voices in the actual, promised, and required resolutions to various problems than differentiating and evaluating the rightness and falseness. This insight complements and extends Sheafer et al.'s (2013: 1272) suggestion that 'a country should strategically structure its international rhetoric so as to emphasize its core values in accordance with its targeted countries'. However, it does not mean that 'respect of differences' (Servaes, 2016: 440) can not be achieved in evaluating the midconduct and wrongness in international communication. Future research may want to examine what strategies can be applied to deal with the negative evaluative messages to bypass the deeply rooted cultural and political differences between countries in the standards of evaluation and reach congruence in the long run.

This study contributes clarity to the ongoing academic debate on China's journalism practice in international communication under the backdrop of soft power projection. Nevertheless, it is restricted by this study's focus on China's involvement in the principle of CBDR in environment and climate issues alone and the sole focus on certain media institutions in China, US, and UK within a short period. Future research may also want to explore the journalistic constructions of China's international responsibility in other global affairs, such as global security and financial issues, by more media institutions in different time spans to expand the academic landscape of China's international communication. Besides answering the question of what the coverages were and how they were constructed guided by the mechanism of cultural and political congruence, future research can also add more depth to this topic by exploring the "why" 
question, for example, the influence of media system and journalists' ideologies on media constructions.

\section{Notes}

1 The UNFCCC is 'a framework for international cooperation to combat climate change by limiting average global temperature increases and the resulting climate change, and coping with impacts that were, by then, inevitable', and the Kyoto Protocol, linked to the UNFCCC, 'commits its Parties by setting internationally binding emission reduction targets'. Their introductions can be found at https://unfecc.int/.

\section{References}

Boc A (2015) The power of language: Globalizing “The Chinese Dream”. Fudan Journal of the Humanities and Social Sciences 8(4): 533-551.

Brownell S (2013) "Brand China" in the Olympic context: Communications challenges of China's soft power initiative. Javnost - The Public 20(4): 65-82.

Chang YL (2003) 'Glocalization' of television: Programming strategies of global television broadcasters in Asia. Asian Journal of Communication 13(1): 1-36.

Cheng Z, Golan GJ and Kiousis S (2016) The second-level agenda-building function of the Xinhua news agency. Journalism Practice 10(6): 744-762.

Commission of the European Communities (2006) EU-China: Closer partners, growing responsibilities. European Commission, 24 October. Available at: http://eurlex.europa.eu/legal-content/EN/TXT/PDF/?uri=CELEX:52006DC0631\&from=EN

Cunningham M (2012) Strategy, Identity Construction, \& China's Quest for Influence: The Role of Rational Self-Interest in Beijing's “Responsible Great Power” Dialogue. Master thesis, American University, USA.

d'Hooghe I (2011) The expansion of China's public diplomacy system. In: Wang J (ed.) Soft power in China: Public Diplomacy through Communication. New York: Palgrave Macmillan, 19-35. 
Ding S (2011) Branding a rising China: An analysis of Beijing's national image management in the age of China's rise. Journal of Asian and African Studies 46(3): 293-306.

Entman RM (2008) Theorizing mediated public diplomacy: The U.S. case. The International Journal of Press/Politics 13(2): 87-102.

Glaser BS and Murphy ME (2009) Soft power with Chinese characteristics: The ongoing debate. In: McGiffert C (ed) Chinese Soft Power and Its Implications for the United States: Competition and Cooperation in the Developing World, A Report of the CSIS Smart Power Initiative. Washington, DC: Center for Strategic and International Studies, 10-26.

Harris PG (2011) Diplomacy, responsibility and China's climate change policy. In: Harris PG (ed.) China's Responsibility for Climate Change: Ethics, Fairness and Environmental Policy. Bristol: Policy Press, 1-21.

Harris PG (2017) China's Paris pledge on climate change: Inadequate and irresponsible. Journal of Environmental Studies and Sciences 7(1): 102-107.

Hartig F (2015) Communicating China to the world: Confucius Institutes and China's strategic narratives. Politics 35(3-4): 245-258.

Hayden C (2012) The Rhetoric of Soft Power: Public Diplomacy in Global Contexts. Lanham, MD: Lexington Books.

Hoo TB (2013) A Responsible Great Power: The Anatomy of China's Proclaimed Identity. PhD thesis, University of Oxford, UK.

Hsieh H-F and Shannon SE (2005) Three approaches to qualitative content analysis. Qualitative Health Research 15(9): 1277-1288. 
Hu Z and Ji D (2012) Ambiguities in communicating with the world: The "Going-out" policy of China's media and its multilayered contexts. Chinese Journal of Communication 5(1): 32-37.

Hu Z, Zhang L and Ji D (2013) Globalization, social reform and the shifting paradigms of communication studies in China. Media, Culture \& Society 35(1): 147-155.

Jang SM, Park YJ and Lee H (2017) Round-trip agenda setting: Tracking the intermedia process over time in the ice bucket challenge. Journalism 18(10): 1292-1308.

Lee SE (2014) Chinese Soft Power through Media Products: Its Projection and Reception in South Korea and Japan. PhD thesis, National University of Singapore, Singapore.

Li C (2010) Treat the media well, use and manage the media effectively. wenming.cn, 4 January. Available at: http://www.wenming.cn/djw/syjj/gcsy/201110/t20111031_369641.shtml

Liang X, Tsai J-Y, Mattis K, Konieczna M and Dunwoody S (2014) Exploring attribution of responsibility in a cross-national study of TV news coverage of the 2009 United Nations Climate Change Conference in Copenhagen. Journal of Broadcasting \& Electronic Media 58(2): 253-271.

Matsui Y (2002) Some aspects of the principle of "Common but Differentiated Responsibilities". International Environmental Agreements: Politics, Law and Economics 2: 151-171.

Merkel A (2007) Opening Address by Angela Merkel, Chancellor of the Federal Republic of Germany, at the World Economic Forum on 24 January 2007 in Davos (transcript). 26 January. Available at: http://www.eu2007.de/en/News/Speeches_Interviews/January/0124BKinDavos.html

Nye JS Jr (1990) Bound to Lead: The Changing Nature of American Power. New York, NY: Basic Books. 
Nye JS Jr (2004) Soft Power: The Means to Success in World Politics. New York, NY: Public Affairs.

Nye JS Jr (2008) Public diplomacy and soft power. The Annals of the American Academy of Political and Social Science 616(1): 94-109.

Nye JS Jr (2010) The Future of Power. New Yok, NY: Public Affairs.

Post S, Königslöw KK and Schäfer MS (2018). Between guilt and obligation: Debating the responsibility for climate change and climate politics in the media. Environmental Communication 1-17.

Rajamani L (2000) The principle of Common but Differentiated Responsibility and the balance of commitments under the climate regime. Review of European Community and International Environmental Law 9(2): 120-131.

Robertson R (1995) Glocalization: Time-space and homogeneity-heterogeneity. In: Featherstone M, Lash S and Robertson R (eds) Global Modernities. Thousand Oaks, CA: Sage, pp. 25-44

Roselle L, Miskimmon A and O'Loughlin B (2014) Strategic narrative: A new means to understand soft power. Media, War \& Conflict 7(1): 70-84.

Sanger DE and Perlez J (2017) Trump hands the Chinese a gift: The chance for global leadership. The New York Times, 1 June. Available at: https://www.nytimes.com/2017/06/01/us/politics/climate-accord-trump-china-globalleadership.html

Servaes J (2016) The Chinese dream shattered between hard and soft power? Media, Culture \& Society 38(3): 437-449.

Sheafer T, Ben-Nun Bloom P, Shenhav SR and Segev E (2013) The conditional nature of value-based proximity between countries: Strategic implications for mediated public diplomacy. American Behavioral Scientist 57(9): 1256-1276. 
Sheafer T and Gabay I (2009) Mediated public diplomacy: A strategic contest over international agenda building and frame building. Political Communication 26(4): 447-467.

Sheafer T and Shenhav SR (2009) Mediated public diplomacy in a new era of warfare. The Communication Review 12(3): 272-283.

Sheafer T, Shenhav SR, Takens J and Atteveldt WV (2014) Relative political and value proximity in mediated public diplomacy: The effect of state-level homophily on international frame building. Political Communication 31(1): 149-167.

Stone CD (2004) Common but differentiated responsibilities in international law. American Journal of International Law 98(2): 276-301.

Sun W (2014) Foreign or Chinese? Reconfiguring the symbolic space of Chinese media. International Journal of Communication 8: 1894-1911.

The White House (2010) National security strategy. Available at: https://www.whitehouse.gov/sites/default/files/rss_viewer/national_security_strategy .pdf (accessed 26 February 2018).

United Nations (1992) Report of the United Nations Conference on Environment and Development. Un.org, 12 Auguest. Available at: http://www.un.org/documents/ga/conf151/aconf15126-1annex1.htm

Vonbun R, Königslöw KK and Schoenbach K (2016) Intermedia agenda-setting in a multimedia news environment. Journalism 17(8): 1054-1073.

Wang J (2006) Managing national reputation and international relations in the global era: Public diplomacy revisited. Public Relations Review 32(2): 91-96.

Wu DD (2008) Patterns of global-local fusion in Chinese internet advertising. In: Wu DD (ed.) Discourses of Cultural China in the Globalizing Age. Hong Kong: Hong Kong University Press, 99-112. 
Xin X (2009) Xinhua News Agency in Africa. Journal of African Media Studies 1(3): 363-377.

Zeng E (2010) CNC World and China's Soft Power: How CNC World Reports Major Global Agenda. Master thesis, National Chengchi University, China.

Zhang T, Khalitova L, Myslik B, Mohr TL, Kim JY and Kiousis S (2018) Comparing Chinese state-sponsored media's agenda-building influence on Taiwan and Singapore media duirng the 2014 Hong Kong Protest. Chinese Journal of Communication 11(1): 66-87.

Zhang X (2008) China as an emerging soft power: Winning hearts and minds through communicating with foreign publics. China Policy Institute Discussion Paper 35.

Zhang X (2013) How ready is China for a China-style world order? China's state media discourse under construction. Ecquid Novi: African Journalism Studies 34(3): 79101.

Zhao Q (2011) Public Diplomacy at Early Stage. China.org.cn, 3 March. Available at: http://www.china.org.cn/china/NPC_CPPCC_2011/201103/03/content_22042058.htm

Zhao X (2017) Responsible China: A Critical Discourse Analysis of Soft Power Projection through Transnational Media. PhD thesis, Bangor University, UK.

Zoellick RB (2005) Whither China: From membership to responsibility? U.S. Department of State, 21 September. Available at: http://20012009.state.gov/s/d/former/zoellick/rem/53682.htm 
Values with Values with

Chinese features Chinese features

but being but being slightly incompatible with different from

Values with Chinese

Values with others'/constructed others'/constructed as being universal as being as being slightly incompatible different (possibility of discussion) features and being Chinese features universally and being identical accepted/constructed with

Success of China's soft power projection

Figure 1. (Constructed) Values in Chinese media and acceptance in the receiving country. 


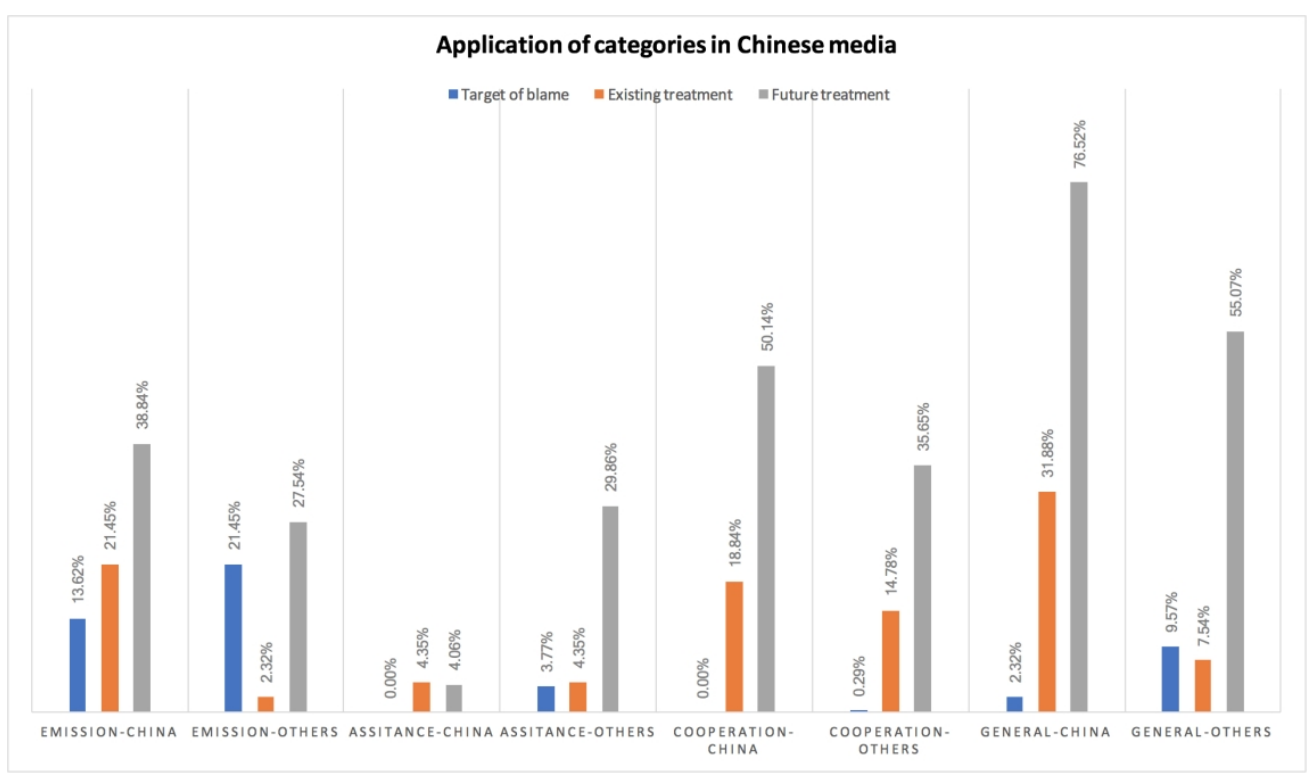

Figure 2. Coverage in Chinese media. 


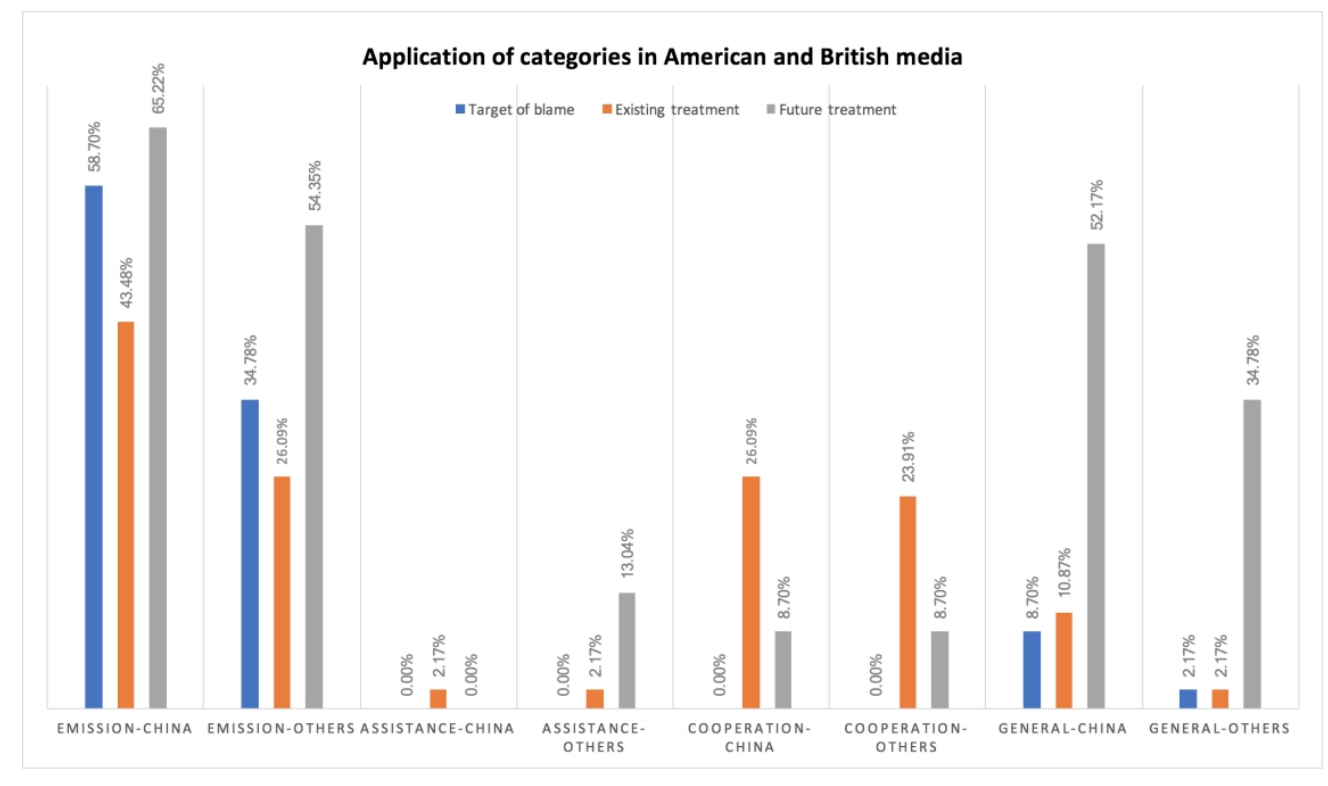

Figure 3. Coverage in American and British media. 